\title{
West Nile virus outbreak in humans, Greece, 2012: third consecutive year of local transmission
}

D Pervanidou (pervanidou@gmail.com) ${ }^{1,2}$, M Detsis' ${ }^{1}$ K Danis ${ }^{1,2}, K_{\text {Kellou }}^{1}$, E Papanikolaou ${ }^{1}$, I Terzaki ${ }^{1}$, A Baka ${ }^{1}$, L Veneti ${ }^{1}$, A

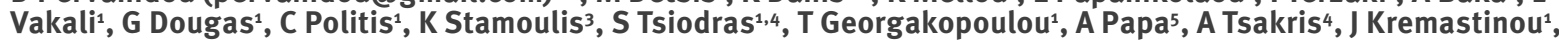

C Hadjichristodoulou 1,6

1. Hellenic Center for Disease Control \& Prevention, Athens, Greece

2. European Programme in Intervention Epidemiology Training (EPIET), European Centre for Disease Prevention and Control (ECDC), Stockholm, Sweden

3. Hellenic National Blood Centre, Athens, Greece

4. Medical Faculty, University of Athens, Athens, Greece

5. Medical Faculty, University of Thessaloniki, Thessaloniki, Greece

6. Medical Faculty, University of Thessaly, Larisa, Greece

Pervanidou D, Detsis M, Danis K, Mellou K, Papanikolaou E, Terzaki I, Baka A, Veneti L, Vakali A, Dougas G, Politis C, Stamoulis K, Tsiodras S, Georgakopoulou T, Papa A, Tsakris A, Kremastinou J, Hadjichristodoulou C. West Nile virus outbreak in humans, Greece, 2012: third consecutive year of local transmission. Euro Surveill. 2014;19(13):pii=20758. Available online: http://www.eurosurveillance.org/ViewArticle.aspx?Articleld=20758

In 2010, the first outbreak of West Nile virus (WNV) infection in Greece was recorded, the largest in Europe since 1996. After 2010, outbreaks continued to occur in different areas of the country. Enhanced surveillance was implemented during transmission periods (June to October). We investigated the 2012 outbreak to determine its extent and identify risk factors for severe disease using regression models. Of 161 cases recorded in 2012, 109 had neuroinvasive disease (WNND). Two outbreak epicentres were identified: the southern suburbs of Athens in July and a rural area in East Macedonia \&Thrace in August-September. The case fatality rate of the WNND cases was $17 \%$ $(18 / 109)$. A lower case fatality rate was recorded in the two epicentres ( $7 \%(2 / 28)$ and $9 \%(4 / 46))$ : the higher case fatality outside the two epicentres might reflect a diagnostic bias. Age above 74 years (adjusted risk ratio (RR): $7.0 ; 95 \% \mathrm{Cl}: 2.2-22$ ) and chronic renal failure (adjusted RR: $4.5 ; 95 \%$ Cl: 2.7-7.5) were independently associated with WNND-related death. In three PCR-positive samples, sequencing revealed WNV lineage 2 identical to the 2010 strain. The occurrence of human cases in three consecutive years suggests that WNV lineage 2 has become established in Greece. Raising awareness among physicians and susceptible populations (elderly people and persons with comorbidities) throughout Greece is critical to reduce the disease impact.

\section{Introduction}

West Nile virus (WNV) is one of the most widely distributed arboviruses in the world, with endemic foci in Africa, the Middle East, west Asia, North and Central America, parts of Europe and Australia [1]. Human cases have been reported from several countries since the 1960s; however, the frequency of reported outbreaks has increased over the last $15-20$ years $[2,3]$.
About $20 \%$ of persons infected with WNV develop a mild disease, usually referred to as West Nile fever (WNF). In less than $1 \%$ of the cases, the virus causes a neuroinvasive disease (WNND) with serious neurological manifestations, i.e. encephalitis, meningitis, meningoencephalitis or acute flaccid paralysis [4]. Among patients with severe illness, the case fatality rate varies (e.g. approximately $10 \%$ in the United States [5] and $12-18 \%$ during transmission periods during 2010 to 2011 in Greece [6]).

Two main WNV genetic lineages are known: lineage 1, identified in the majority of the outbreaks in humans and horses in Europe and the United States and lineage 2, which until 2004 had not been detected outside Africa, but since then has repeatedly appeared - initially in Hungary in 2004 [7] and 2005-09 [8], in Russia in 2007 [9] and in Austria in 2008-09 [8,10].

Before 2010, symptomatic human cases of WNV infection had not been documented in Greece. However, serosurveys in the early 605,805 and in 2007 suggest that WNV or a related flavivirus had been circulating at low levels in Greece at least since the 6os [11-13]. The first recorded outbreak of WNV infection in Greece was in 2010: this was the largest reported outbreak in Europe since 1996 [14], with 262 recorded cases. Of these, 197 developed WNND, of whom 33 (17\%) died [15]. A seroprevelence study conducted after the 2010 outbreak (between 25 November to 22 December 2010) indicated that 1 in 140 people infected with WNV developed WNND [16].

The outbreak in 2010 was first detected in the Central Macedonia region, in northern Greece $[15,17]$. Surveillance in the blood donor population and posttransfusion information during the 2010 outbreak 
showed that the estimated risk of infected blood donations in the affected areas, associated with collecting blood from asymptomatic donors (based on the method proposed by Biggerstaff and Petersen [18], which is recommended in the 2012 European Union (EU) preparedness plan for WNV and blood safety [19]) was 2.95 per 10,000 population. Transfusion-transmitted WNV infection was recorded in two of 369 thalassaemic patients in 2010 (incidence 1:2,397 transfused units of red cell concentrates), before the implementation of blood safety measures in this year $[20,21]$.

In 2011, cases of WNV infection occurred in the same districts as in 2010. In addition, the virus dispersed southward to the region of Thessaly, and further south to Eastern Attica, in proximity to the metropolitan area of Athens [6]. Overall, 100 human cases were identified, 75 of whom had WNND and nine (12\%) of the WNND cases died.

WNV lineage 2 sequences (strain Nea SantaGreece-2010) were obtained from blood donors, mosquitoes and birds in the transmission period (June to October) of both years [22-27].

In 2012, cases of WNV infection were first reported to the Hellenic Center for Disease Control \& Prevention in June. Here we present the analysed epidemiological data gathered during the 2012 transmission period in order to describe the outbreak in terms of time, place and person and identify possible factors associated with disease severity.

\section{Methods}

\section{Surveillance}

Following the 2010 outbreak, physicians (public and private sector) in Greece were asked to include WNV infection in their differential diagnosis during the transmission period and notify daily suspected and laboratory-diagnosed cases to the Hellenic Center for Disease Control \& Prevention. In parallel, during this period, daily information exchange with the laboratories involved in the diagnosis of WNV infection was established for timely case identification and investigation.

\section{Outbreak case definition}

The 2008 European Union case definition for WNV infection [28] was used with a slight modification, i.e. the definition of probable cases included clinical and laboratory - but not epidemiological - criteria).

\section{Data collection}

We collected information regarding the demographic characteristics, clinical manifestations, underlying chronic diseases and laboratory results of all the cases reported in 2012 by using standardised reporting forms. We telephoned treating physicians of all reported cases for data validation and follow up of the patients' clinical status. Moreover, in-depth telephone interviews with all cases or their close relatives (as proxy respondents, when cases had severe disease and/or cognitive problems) using a semi-structured questionnaire were conducted to obtain a detailed travel history during the incubation period (2-14 days before symptom onset) and identify the suspected place of exposure.

Cases reported as having encephalitis (including meningoencephalitis), meningitis or acute flaccid paralysis were classified as having WNND. WNND classification was based on the treating physicians' clinical assessment and laboratory data (detection of WNV nucleic acid and/or WNV-specific antibody response in cerebrospinal fluid (CSF) and/or imaging findings), when available. Deaths in persons with WNV infection were recorded during hospitalisation.

Municipalities (the lowest administrative unit) with at least one human laboratory- diagnosed case of WNV infection during the 2012 transmission period were classed as affected areas.

We assigned week numbers using the International Organization for Standardization (ISO) 8601 standard [29].

\section{Blood safety measures}

Measures for the protection of blood donations against WNV infection were implemented in the affected areas. These included blood donor deferral, blood screening for WNV RNA and haemovigilance (a set of organised surveillance procedures related to serious adverse or unexpected events or reactions in donors or recipients and the epidemiological follow-up of donors, according to the eligibility criteria of donors of whole blood and blood components as referred to in article 4 and annex III of the Commission Directive 2004/33/EC [30]).

\section{Laboratory methods}

We obtained laboratory data from the four laboratories in which all the suspected WNV infection cases from all over Greece were tested: (i) National Reference Laboratory for Arboviruses, School of Medicine, Aristotle University of Thessaloniki; (ii) Department of Microbiology, School of Medicine, University of Athens; (iii) Department of Microbiology, Infectious Disease Hospital of Thessaloniki; and (iv) Department of Diagnostic Services, Hellenic Pasteur Institute.

Serum and CSF specimens were tested for IgM and IgG against WNV by ELISA (WNV IgM capture DxSelect and WNV IgG DxSelect, respectively, Focus Diagnostics Inc, Cypress, CA, United States). A real-time reverse-transcription (RT)-PCR [31] and an RT-nested PCR [32] were used.

After the diagnosis of the first human case, screening of donated blood for WNV RNA with targeted individual donation (ID) nucleic acid amplification testing (NAT) using the Procleix WNV Assay [33] or minipool 


\section{FIGURE 1}

Laboratory-diagnosed (confirmed and probable) cases of West Nile neuroinvasive disease by week ${ }^{\mathrm{a}}$ of symptom onset, Greece, $2010(n=197), 2011(n=75), 2012(n=109)^{b}$

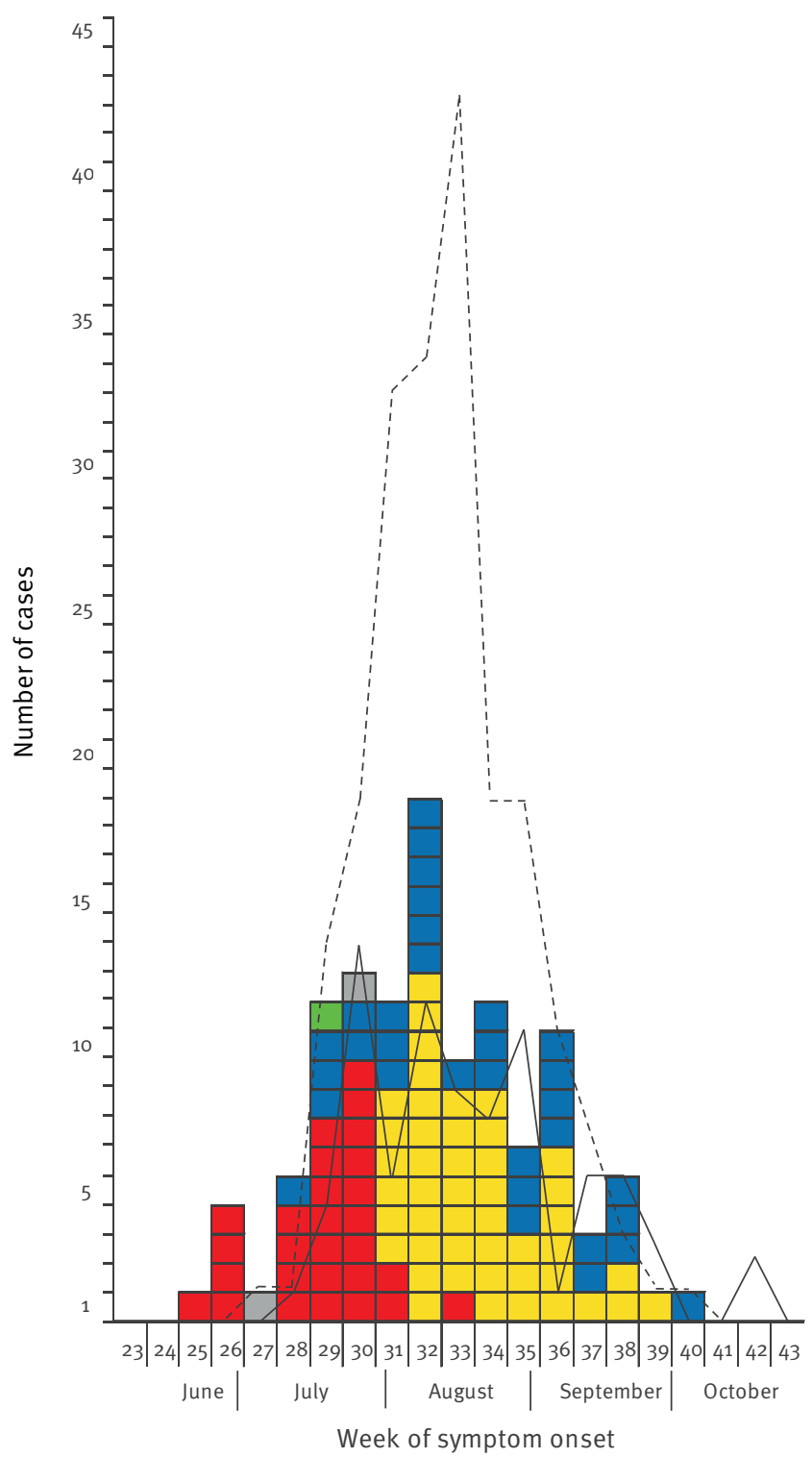

Southern suburbs of Athens

East Macedonia \& Thrace region

Other areas

Undetermined place of exposure

Transmission through blood transfusion

- 2011 cases with WNND

--. 2010 cases with WNND

WNND: West Nile neuroinvasive disease.

${ }^{a}$ Week number is according to the International Organization for Standardization (ISO) 8601 standard.

${ }^{b}$ Each box represents one laboratory-diagnosed case of WNND reported in 2012
(MP) NAT of equal aliquots of six individual donations using the Gobas TaqScreen West Nile Virus Test [34] was implemented in the affected areas, from 11 July to 10 November. The screening was carried out in five Blood Centres (three in Athens, one in Thessaloniki and another in Alexandroupoli).

Data analysis

Descriptive analysis of the surveillance data was conducted, including the geographical and temporal distribution of WNND cases, age, sex, clinical manifestations, underlying diseases and clinical outcome.

We calculated risk ratios (RRs) to compare the incidence of WNND in different populations. Urban and rural areas were defined according to the Hellenic Statistical Authority data [35]: townships with more than 2,000 residents were classified as urban.

To identify predictive factors of developing WNND versus WNF, we calculated odds ratios (ORs), as WNF reported cases represented a small fraction of all WNF infections in the population [16]. An association was considered statistically significant when the $p$ value was $\leq 0.05$.

We constructed multiple logistic regression models to identify factors independently associated with disease severity. Initials models included all variables for which the $p$ value was $<0.1$ or the OR was $>1.10$ or $<0.90$. We removed variables one at a time, depending on the significance testing ( $p<0.05)$ by the likelihood ratio test. We estimated adjusted RRs from binomial regression analysis including all variables that remained significant in the final logistic regression model. Imported cases and asymptomatic infections detected through haemovigilance were not included in the analysis.

The analysis was carried out using STATA version 12 software (Stata Corporation LP, Texas, United States).

\section{Results}

\section{Descriptive analysis}

In 2012, 163 cases of WNV infection were recorded. Two of the cases were classified as imported from the United States. Of the 161 locally acquired cases, 109 (47 confirmed and 62 probable) were classified as WNND and 52 (one confirmed and 51 probable) as WNF. The overall WNND incidence was one case per 100,000 population. One of the WNND reported cases was a Greek traveller whose infection was diagnosed in Germany [36]. Close relatives of $83 \%(n=91)$ of the 109 WNND cases, with severe disease and/or cognitive problems, were interviewed.

All cases occurred within a 16-week interval from 20 June (week 25) to 7 October 7 (week 41) 2012 and the outbreak peaked in the second week of August (Figure 1). The median period from symptom onset to diagnosis 
Incidence (per 100,000 population) of West Nile neuroinvasive disease by suspected municipality of exposure, Greece, JuneOctober $2012(\mathrm{n}=106)^{\mathrm{a}}$

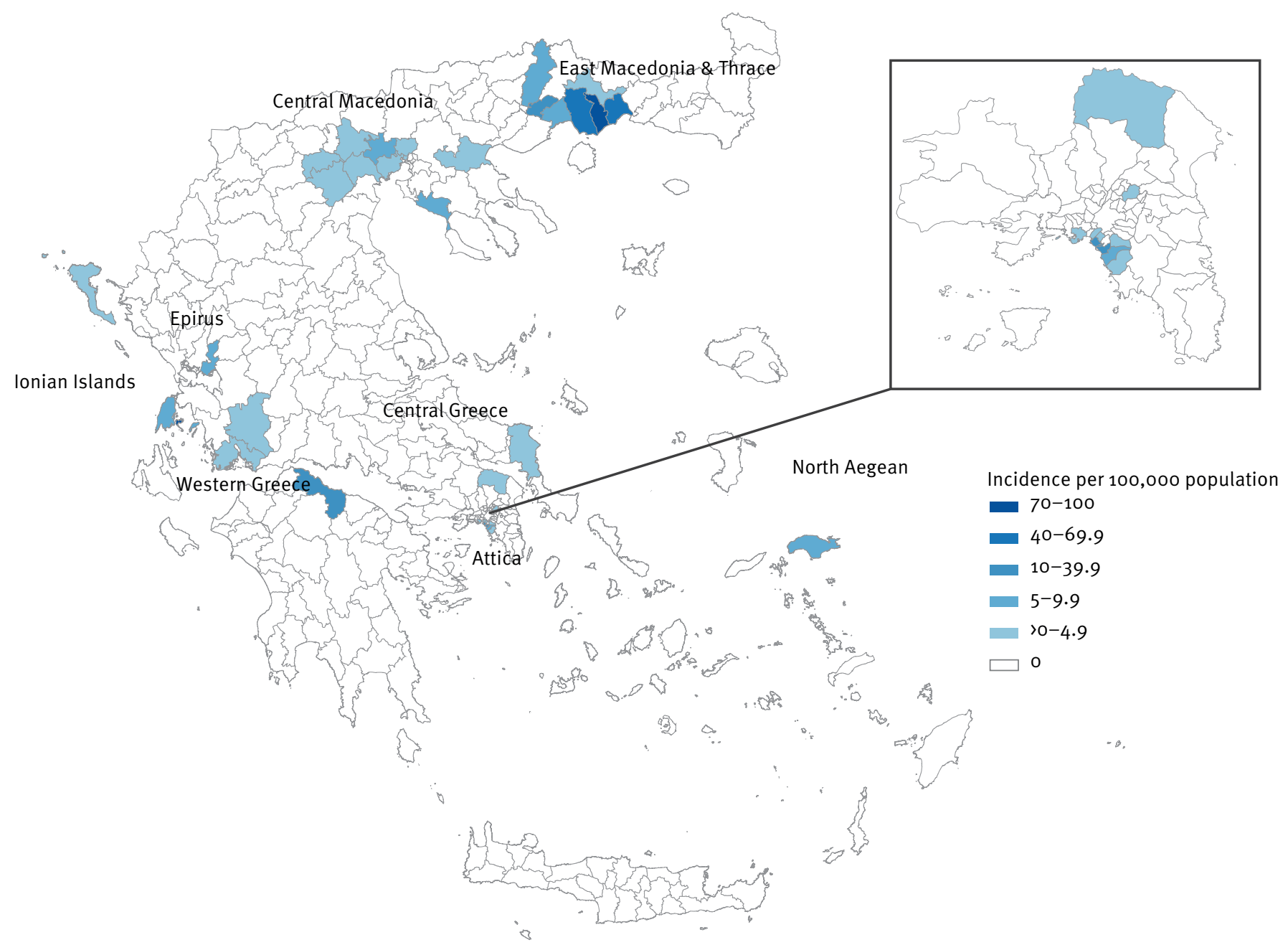

${ }^{a}$ The place of exposure could not be determined for two cases. One patient acquired the infection through blood transfusion and is also not included in the map.

for the WNND cases was 7 days (range: $2-53$ ) and the mean was 9.29 (SD: 6.98) days.

Haemovigilance procedures demonstrated that one WNND case acquired the infection through blood transfusion: this patient was admitted to the intensive care unit and recovered. Another person transfused with a blood component derived from the same unit of blood from the implicated donor was also infected but did not develop symptoms. It is important to emphasise that blood collection from the implicated donor and both transfusions took place before diagnosis of the first case of WNV infection in Greece in 2012, which triggered the implementation of blood safety measures against WNV infection. Details of these haemovigilance findings and data on surveillance in the blood donor population will be presented elsewhere.
For two WNND cases, the probable place of exposure could not be determined, due to their complicated travel history during the incubation period. The remaining 106 WNND cases were infected in 19 of the 74 regional units of the country, in eight regions (Figure 2); $55 \%$ (58/106) of the cases occurred in eight regional units that had not been previously affected.

During the 2012 transmission period, two main outbreak epicentres were identified. From 20 June (week 25) to 16 August (week 33), $26 \%(n=28)$ of the 106 WNND cases occurred in the southern suburbs of Athens in Attica (incidence: 3.6 per 100,000 population): this had not been previously considered an established area for WNV. Six weeks after the beginning of the outbreak, and as the number of new cases was substantially decreasing in Attica, a second epicentre was detected in a newly affected rural wetland area in the 
Characteristics of cases with West Nile neuroinvasive disease, Greece, June-October 2012 ( $\mathrm{n}=109)$

\begin{tabular}{|l|c|c|c|}
\hline Characteristic & $\begin{array}{c}\text { Number of } \\
\text { cases (\%) }\end{array}$ & $\begin{array}{c}\text { Incidence } \\
\text { (per 100,000 } \\
\text { population) }\end{array}$ & $\begin{array}{c}\text { Risk ratio } \\
(95 \% \mathrm{CI})\end{array}$ \\
\hline Age group in years \\
\hline$<20$ & $2(2)$ & 0.09 & Reference \\
\hline $20-29$ & $3(3)$ & 0.23 & $2.5(0.42-15)$ \\
\hline $30-39$ & $3(3)$ & 0.17 & $1.9(0.32-11)$ \\
\hline $40-49$ & $4(4)$ & 0.23 & $2.6(0.47-14)$ \\
\hline $50-59$ & $12(11)$ & 0.80 & $8.7(1.9-39)$ \\
\hline $60-69$ & $29(27)$ & 2.34 & $26(6.1-107)$ \\
\hline $70-79$ & $31(28)$ & 2.94 & $32(7.7-134)$ \\
\hline$\geq 80$ & $25(23)$ & 4.22 & $46(11-194)$ \\
\hline Sex & $38(35)$ & 0.67 & Reference \\
\hline Female & $71(65)$ & 1.27 & $1.9(1.3-2.8)$ \\
\hline Male & $55(52)$ & 0.67 & Reference \\
\hline Place of exposure & 1.87 & $2.8(1.9-4.1)$ \\
\hline Urban & $51(48)$ &
\end{tabular}

a Percentages do not sum to $100 \%$ as a result of rounding.

b Population data from Hellenic Statistical Authority (EL. STAT.) [56].

Three cases are not included (two cases with undetermined place of exposure and one case infected through blood transfusion).

Source: Hellenic Center for Disease Control \& Prevention.

region of East Macedonia \& Thrace, with 43\% (46/106) of the WNND cases (incidence: 17.6 per 100,000 population), from 30 July (week 31) to 27 September (week 39) (Figure 1). Among these cases, 41 were recorded in the regional units of Xanthi and Kavala. The remaining cases mainly occurred in the regions of Central Macedonia $(n=15)$ and Western Greece $(n=7)$.

Among the WNND cases, $52 \%$ (55/106) were residents of urban areas, while the incidence of WNND in rural settings was almost three times higher than that in urban areas (Table 1). All 28 WNND cases in the southern suburbs of Athens and 11/46 of the cases in the region of East Macedonia \& Thrace were from urban areas. In rural areas, the incidence of WNND was significantly higher among people who were male (RR: 2.3; $95 \% \mathrm{Cl}: 1.2-4.2, p=0.005)$, whereas in urban areas, the difference between the sexes was not statistically significant (RR: $1.6 ; 95 \% \mathrm{Cl}: 0.91-2.7, \mathrm{p}=0.10$ ).

The median age of WNND cases was 70 years (range: $11-95)$ and $65 \%(71 / 109)$ were male. The incidence of WNND cases increased from 0.17 per 100,000 in the 30-39 year-olds to 4.22 per 100,000 in those who were $\geq 80$ years-old (Table 1 ). The median age and sex distribution of patients with WNND in the two epicentres did not significantly differ $(p=0.93$ and $p=0.87$, respectively).
Encephalitis/meningoencephalitis (83\%; 90/109) was the most prominent clinical syndrome, followed by meningitis $(16 \% ; 17 / 109)$ and acute flaccid paralysis $(5 \% ; 5 / 109)$. In two patients, acute flaccid paralysis was the only symptom.

Fever was the most commonly reported symptom among WNND cases $(99 \% ; 106 / 107)$, followed by fatigue $(84 \% ; 83 / 99)$, confusion $(79 \% ; 82 / 104)$, weakness $(74 \% ; 73 / 98)$, headache $(69 \% ; 69 / 100)$, myalgia $(62 \% ; 56 / 91)$, arthralgia $(56 \% ; 48 / 85)$, chills $(55 \%$; 52/94), gastrointestinal symptoms (48\%; 52/109), extrapyramidal signs/tremor $(29 \% ; 29 / 100)$, rash $(16 \%$; $16 / 101)$ and limb paresis (15\%; 15/100).

Of the 109 WNND cases, 83 (76\%) had at least one underlying chronic disease, with 54/109 (50\%) cases having two or more coexisting conditions. The most commonly reported underlying conditions among the 109 WNND cases were hypertension $(45 \% ; n=49)$, diabetes mellitus ( $35 \% ; n=38)$, heart disease $(21 \% ; n=23)$, cancer (11\%; $n=12)$, chronic neuropsychiatric disease $(10 \% ; n=11)$, stroke $(9 \% ; n=10)$, chronic renal failure $(6 \% ; n=7)$ and chronic respiratory disease $(6 \% ; n=6)$. Chronic neuropsychiatric disease included dementia, epilepsy, Parkinson disease and psychosis.

Of 80 WNND cases with the relevant information, 56 reported having agricultural/gardening activities and/ or other outdoor activities in the countryside, while 21 of 94 cases reported having outdoor activities at night.

All 109 WNND identified cases were hospitalised and $18(17 \%)$ were admitted to an intensive care unit (ICU).

\section{Predictive factors of disease severity}

\section{Predictive factors of WNND versus WNF}

The median age of WNND cases (70 years; range: 11-95) was significantly higher $(p=0.001)$ than that of the diagnosed WNF cases (63 years; range: 14-92).

In the univariable analysis, the odds of WNND among all reported cases of WNV infection increased significantly (OR: 1.03; $95 \% \mathrm{Cl}: 1.01-1.05)$ with increasing age and was significantly higher among cases who were male (OR: 2.8; $95 \% \mathrm{Cl}: 1.3-5.8$ ) (Table 2).

Patients with WNND were twice as likely to have at least one underlying condition than patients with WNF and almost three times more likely to have more than one underlying condition (Table 2).

Age ( $\geq 75$ years) and male sex were the only factors associated with the presence of WNND in the final logistic regression model (Table 2). 
Demographic characteristics and underlying conditions of reported cases with West Nile neuroinvasive disease ( $\mathrm{n}=109)$ and West Nile fever $(n=52)$, Greece, June-October 2012

\begin{tabular}{|c|c|c|c|c|}
\hline Characteristic & $\begin{array}{c}\text { WNND } \\
\text { Number (\%) }\end{array}$ & $\begin{array}{c}\text { WNF } \\
\text { Number (\%) }\end{array}$ & $\begin{array}{l}\text { Crude odds ratio } \\
(95 \% \mathrm{Cl})\end{array}$ & $\begin{array}{c}\text { Adjusted odds ratio }{ }^{\mathrm{a}} \\
(95 \% \mathrm{Cl})\end{array}$ \\
\hline \multicolumn{5}{|l|}{ Age group in years } \\
\hline$<75$ & $67(61)$ & $43(83)$ & Reference & Reference \\
\hline$\geq 75$ & $42(39)$ & $9(17)$ & $3.0(1.3-7.7)$ & $3.5(1.5-8.1)$ \\
\hline \multicolumn{5}{|l|}{ Sex } \\
\hline Female & $38(35)$ & $31(60)$ & Reference & Reference \\
\hline Male & $71(65)$ & $21(40)$ & $2.8(1.3-5.8)$ & $3.1(1.5-6.4)$ \\
\hline \multicolumn{5}{|l|}{ Co-morbidity } \\
\hline No underlying conditions & $26(24)$ & $21(40)$ & Reference & \multirow{4}{*}{ NA } \\
\hline One underlying condition & $29(27)$ & $16(31)$ & $1.5(0.63-3.4)$ & \\
\hline$\geq 2$ underlying conditions & $54(50)$ & $15(29)$ & $2.9(1.3-6.5)$ & \\
\hline$\geq 1$ underlying conditions & $83(76)$ & $31(60)$ & $2.2(1.0-4.6)$ & \\
\hline \multicolumn{5}{|l|}{ Underlying conditions } \\
\hline Hypertension & $49(45)$ & $19(37)$ & $1.4(0.68-3.0)$ & \multirow{8}{*}{ NA } \\
\hline Heart disease & $23(21)$ & $9(17)$ & $1.3(0.51-3.4)$ & \\
\hline Diabetes & $38(35)$ & $13(25)$ & $1.6(0.73-3.7)$ & \\
\hline Cancer & $12(11)$ & $3(6)$ & $2.0(0.51-12)$ & \\
\hline Chronic neuropsychiatric disease & $11(10)$ & $3(6)$ & $1.8\left(0.45^{-11}\right)$ & \\
\hline Stroke & $10(9)$ & $1(2)$ & $5.2(0.69-228)$ & \\
\hline Chronic renal failure & $7(6)$ & $1(2)$ & $3.5(0.43-161)$ & \\
\hline Chronic respiratory disease & $6(6)$ & $1(2)$ & $3.0(0.34-139)$ & \\
\hline
\end{tabular}

NA: not applicable; WNF: West Nile fever; WNND: West Nile neuroinvasive disease.

${ }^{a}$ Adjusted for age and sex.

Source: Hellenic Center for Disease Control \& Prevention.

Predictive factors of encephalitis/meningoencephalitis versus meningitis

The median age (72 years; range: $19-95)$ of cases with encephalitis/meningoencephalitis was significantly higher ( $p<0.001)$ than that of cases with meningitis ( 57 years; range: $11-80$ ). The risk of developing encephalitis increased by $4 \%$ for each yearly increase in age (OR for trend: $1.04 ; 95 \% \mathrm{Cl}: 1.0-1.1)$.

Patients with at least one underlying condition (OR adjusted for age: $4.2 ; 95 \% \mathrm{Cl}: 1.0-17)$ were more likely to develop encephalitis/meningoencephalitis than meningitis.

\section{Predictive factors of fatal outcome}

A total of 18 WNND cases died, indicating an overall case fatality rate of $17 \%$. The case fatality rate in the two main epicentres (southern suburbs of Athens, East Macedonia \& Thrace) was lower, $7 \%(2 / 28)$ and $9 \%$ (4/46), respectively, than the rate recorded outside the main epicentres (34\%; 12/35).

The median age of the fatal cases was 79 years (range: 72-95), with the age-specific case fatality rate in patients aged $\geq 75$ years reaching $36 \%$ (15/42) (Table 3).
The case fatality rate did not differ significantly between sexes $(p=0.69)$. Eight of the 18 WNND fatalities were hospitalised in an ICU. The median interval from WNV symptom onset to death was 16 days (range: 4-108).

Of the 18 patients with a fatal outcome, 16 had encephalitis/meningoencephalitis (one of whom also had acute flaccid paralysis) and two had meningitis. The risk of fatal outcome among WNND cases did not significantly differ $(p=0.54)$ between cases with encephalitis/meningoencephalitis and cases with meningitis.

All patients who died had at least one underlying condition. Co-morbidity was a significant $(p=0.009)$ risk factor for death, with the case fatality rate being almost six times higher among patients with chronic renal failure. Age ( $\geq 75$ years) and chronic renal failure remained independent predictive factors of death in the multivariable analysis (Table 3 ).

The case fatality rate, adjusted for age and chronic renal failure, did not differ significantly in the two epicentres $(p=0.667)$; however, it was significantly higher in Western Greece (RR: 4.9; 95\% Cl: 1.4-17) and Central 


\section{TABLE 3}

Factors predicting death for cases with West Nile neuroinvasive disease, Greece, June-October 2012 (n=109)

\begin{tabular}{|c|c|c|c|c|}
\hline Characteristic & $\begin{array}{l}\text { Number of deaths } \\
(n=18)\end{array}$ & Case fatality rate (\%) & $\begin{array}{l}\text { Crude risk ratio } \\
(95 \% \mathrm{Cl})\end{array}$ & $\begin{array}{c}\text { Adjusted risk ratiob } \\
(95 \% \mathrm{Cl})\end{array}$ \\
\hline \multicolumn{5}{|l|}{ Age group in years } \\
\hline$\langle 75$ & $3^{c}$ & 4.48 & Reference & Reference \\
\hline$\geq 75$ & 15 & 35.71 & $8.0(2.5-26)$ & $7.0(2.2-22)$ \\
\hline \multicolumn{5}{|l|}{ Sex } \\
\hline Female & 7 & 18.42 & Reference & \multirow{2}{*}{ NA } \\
\hline Male & 11 & 15.49 & $0.84(0.36-2.0)$ & \\
\hline \multicolumn{5}{|l|}{ Clinical manifestation } \\
\hline Meningitis & 2 & 11.76 & Reference & \multirow{2}{*}{ NA } \\
\hline Encephalitis/meningoencephalitis & 16 & 17.78 & $1.5(0.38-6.0)$ & \\
\hline \multicolumn{5}{|l|}{ Co-morbidity } \\
\hline 1 underlying condition & 5 & 17.24 & Reference & \multirow{3}{*}{ NA } \\
\hline 2 underlying conditions & 7 & 20.00 & $1.16(0.41-3.3)$ & \\
\hline$\geq 3$ underlying conditions & 6 & 31.58 & $1.83(0.65-5.2)$ & \\
\hline \multicolumn{5}{|l|}{ Underlying conditions } \\
\hline \multicolumn{5}{|l|}{ Hypertension } \\
\hline No & 9 & 15.00 & Reference & \multirow{2}{*}{ NA } \\
\hline Yes & 9 & 18.37 & $1.22(0.53-2.9)$ & \\
\hline \multicolumn{5}{|l|}{ Heart disease } \\
\hline No & 12 & 13.95 & Reference & \multirow{2}{*}{ NA } \\
\hline Yes & 6 & 26.09 & $1.9(0.79-4.4)$ & \\
\hline \multicolumn{5}{|l|}{ Diabetes } \\
\hline No & 9 & 12.68 & Reference & \multirow{2}{*}{ NA } \\
\hline Yes & 9 & 23.68 & $1.9(0.81-4.3)$ & \\
\hline \multicolumn{5}{|l|}{ Chronic neuropsychiatric disease } \\
\hline No & 14 & 14.29 & Reference & \multirow{2}{*}{ NA } \\
\hline Yes & 4 & 36.36 & $2.5(1.0-6.4)$ & \\
\hline \multicolumn{5}{|l|}{ Cancer } \\
\hline No & 15 & 15.46 & Reference & \multirow{2}{*}{ NA } \\
\hline Yes & 3 & 25.00 & $1.6(0.55-4.8)$ & \\
\hline \multicolumn{5}{|l|}{ Stroke } \\
\hline No & 15 & 15.15 & Reference & \multirow{2}{*}{ NA } \\
\hline Yes & 3 & 30.00 & $2.0(0.69-5.7)$ & \\
\hline \multicolumn{5}{|l|}{ Chronic renal failure } \\
\hline No & 13 & 12.75 & Reference & Reference \\
\hline Yes & 5 & 71.43 & $5.6(2.8-11)$ & $4.5(2.7-7.5)$ \\
\hline \multicolumn{5}{|l|}{ Chronic respiratory disease } \\
\hline No & 16 & 15.53 & Reference & \multirow{2}{*}{ NA } \\
\hline Yes & 2 & 33.33 & $2.1(0.63-7.3)$ & \\
\hline
\end{tabular}

NA: not applicable.

${ }^{a}$ Case fatality rate refers to the percentage of fatalities among cases within a specific characteristic category.

${ }^{b}$ Includes variables that remained significant in the final binomial regression model.

' Belonged to the 70-74 year age group.

Source: Hellenic Center for Disease Control \& Prevention. 
Macedonia (RR: $4.1 ; 95 \% \mathrm{Cl}: 1.2-15)$, compared with that of cases in the southern suburbs of Athens.

\section{Laboratory results}

Of the 161 locally acquired cases, 45 had a WNVspecific IgM antibody response in CSF (confirmed cases), 113 had WNV-specific IgM antibody response in serum (probable cases, CSF sample was not available) and in three (confirmed) cases (one from the south suburbs of Athens and two from East Macedonia), WNV nucleic acid was detected in blood or urine. In these three cases, sequencing revealed WNV lineage 2 , with sequences with $100 \%$ genetic similarity (in the amplified fragment of the NS3 gene) with the Nea Santa-Greece-2010 strain (GenBank Accession number HQ537483) [23]). The whole genome sequence was obtained from a urine sample from a patient with WNND in the regional unit of Kavala, East Macedonia (strain Greece/2012/Kavala, GenBank accession number KF179639; the strain presented $99.7 \%$ sequence identity with the Nea Santa-Greece-2010 strain) [37].

As in previous years, there was no cross-reactivity with tick-borne encephalitis virus, while cross-reactivity was seen with Dengue virus (DENV); however, when a positive result was obtained for DENV, the titres were lower than those against WNV [38]. None of the patients had been previously vaccinated against yellow fever or Japanese encephalitis.

Of the 36,911 blood units tested by NAT $(76.4 \%$ $(n=28,205)$ ID-NAT and $23.6 \%(n=8,706) \quad$ MP-NAT $)$, four $(1: 9,228)$ were positive, including the one found through haemovigilance procedures.

\section{Discussion}

Human WNV infections were notified in Greece in 2012 for the third consecutive year in the context of an enhanced surveillance system in place since 2010. A new geographical pattern of WNV circulation was observed, with a more dispersed distribution of cases and two outbreak epicentres (one in a rural and one in an urban area) with different temporal patterns. The reason for this distinct temporal distribution is not clear. It might reflect different microclimatic conditions (such as temperature), vector distribution or bird migration patterns between the two areas. In addition, more than half of the reported cases occurred in areas that had not been affected in previous years, outlining the difficulty in predicting WNV circulation and defining areas at risk for following years. In 2013, cases continued to occur in previously affected areas, but also in one new regional unit [39].

This outbreak was the largest recorded in the European Union (EU) in 2012 and the second largest among the EU countries reporting to the European Centre for Disease Prevention and Control (ECDC) and information compiled by ECDC (the largest being in Russia, with 447 cases, and then followed by Israel with 83 cases, Serbia with 69, and Italy with 50) [40]. The 2012 incidence of WNND cases in Greece was $50 \%$ higher than in 2011, but remained lower than that in 2010. The first human cases occurred earlier than in previous years (26 and 16 days earlier than the first case of 2011 and 2010, respectively), probably due to the higher temperatures recorded in June 2012, especially in central and southern Greece. In the southern suburbs of Athens, the mean temperature in June 2012 was $28.6{ }^{\circ} \mathrm{C}$, whereas in June 2011 and 2010 it was $25.4{ }^{\circ} \mathrm{C}$ and $26.1{ }^{\circ} \mathrm{C}$, respectively [41] ${ }^{*}$. However, the effects of climatic conditions e.g. temperature and humidity, on local vector populations need further study.

All three obtained sequences from the PCR-positive samples belonged to WNV lineage 2 , with $100 \%$ genetic similarity with the strain detected in 2010, suggesting that this strain has become established in Greece. In addition, WNV lineage 2 sequences were also obtained from Culex spp. mosquitoes collected in the regional unit of Xanthi, in the municipality with the highest incidence in Greece in 2012; as in the strain circulating in the two previous transmission periods, the strain contained the $\mathrm{H}_{249} \mathrm{P}$ substitution in the $\mathrm{NS}_{3}$ protein (GenBank accession number JX860675) [42], which might be associated with increased virulence of the strain [23].

One WNND case acquired the infection through blood transfusion before the implementation of blood safety measures, including screening of donor blood for WNV RNA by NAT in the affected areas in 2012. It should be noted that the blood donor involved gave blood eight days before the first confirmed human case was diagnosed and reported to the Hellenic Center for Disease Control \& Prevention.

The higher incidence of WNND among male patients is consistent with findings from other countries [43], probably reflecting behavioural factors leading to increased exposure to mosquitoes, especially in rural areas. The majority of the WNND cases reported outdoor activities, which has also been identified as a risk factor for developing the disease [44]. Older age ( $\geq 75$ years) was also found to be significantly associated with a higher risk of severe neurological disease. The association between age and severe disease has been well established $[14,43,45-52]$.

The overall case fatality rate (17\%) among patients with WNND was higher than that in other countries $[14,43$, $45-48,53]$ and similar to that recorded in the 2010 outbreak in Greece $(17 \%)^{*}$ and the $2008-11$ outbreak in Italy (16\%) [54]. The high case fatality rate in regions with fewer reported cases might reflect a diagnostic bias: in areas where physicians were not sensitised to test all suspected cases for WNV infection, only the most severe cases were likely to be diagnosed, including those with a fatal outcome. More research is required to investigate the reasons for the regional difference in case fatality rate. 
In our study, advanced age was found to independently predict WNND-related death, a finding compatible with many previous studies $[14,43,45,46,48-50,52]$. The literature is inconsistent regarding whether pre-existing medical conditions are predictive of WNND or death $[49-52,55]$. In our study, co-morbidity was not found to predict WNND; however, chronic renal failure was significantly associated with a fatal outcome. Specific underlying conditions (such as diabetes, immunosuppression, history of stroke) have been identified as risk factors for fatal outcome $[48,50-52,55]$, while some other studies showed an association between chronic renal disease and severe WNV infection [55] or death [51], as in our study.

Limitations should be taken into account when interpreting our findings. The cases detected by the enhanced surveillance system represent the severe cases of WNV infection. Moreover, diagnosed WNF cases are considered to represent a small fraction of all WNF cases (probably the more serious in the spectrum of mild illness), as mild WNF cases are less likely to be diagnosed and reported. Moreover, central nervous system involvement was not always validated by laboratory or imaging results. Finally, the ORs and case fatality rates should be interpreted with caution, as small numbers are involved for some risk factors and outcome categories.

In conclusion, the occurrence of human cases of WNV infection in three consecutive years and the spread of the virus in newly affected areas suggest that WNV, and specifically WNV lineage 2 , is established in Greece and transmission is expected to continue in the future. WNV circulation continued in 2013, with 86 diagnosed cases (51 of whom had WNND) [39].The established enhanced surveillance of WNV infection among humans and animals, comprehensive vector control and the implementation of the recommended blood safety and haemovigilance measures during the transmission period constitute the cornerstones of successful management of this seasonal public health threat.

Ongoing health education campaigns, including seminars and dissemination of information material, targeting specifically susceptible populations (i.e. the elderly and those with co-morbidities, including chronic renal failure) and physicians throughout the country may lead to more effective disease prevention and decreased numbers of fatalities.

\section{* Authors' correction}

The following corrections were made at the request of the authors on 4 April 2014: the 2011 and 2010 mean temperatures in the southern suburbs of Athens were corrected. In addition, some details of references 20, 21, 35 and 56 were amended. On 5 April 2014, the case fatality rate in the 2010 outbreak in Greece was amended.
Acknowledgments

We would like to thank all hospital physicians, laboratory personnel and local public health authorities who contributed to the surveillance of WNV infections in Greece, and especially the Xanthi's and Kavala's Directorates of Public Health and Social Welfare; the Microbiological Department of the Infectious Disease Hospital of Thessaloniki and the Hellenic Pasteur Institute for their contribution to the laboratory surveillance; all partners of the project 'Integrated surveillance and control programme for West Nile virus and malaria in Greece' (MALWEST) funded by the National Strategic Reference Framework 2007-13; and A Liona and A Ntakou, for their administrative support in surveillance activities.

\section{Conflict of interest}

None declared.

Authors' contributions

Danai Pervanidou, Kostas Danis, Marios Detsis, Theano Georgakopoulou, Sotirios Tsiodras, Agoritsa Baka, Jenny Kremastinou and Christos Hadjichristodoulou contributed to the surveillance and outbreak response.

Danai Pervanidou conducted the analysis and wrote the first draft of this manuscript. Kostas Danis and Kassiani Mellou contributed to the data analysis and the writing of the first draft. Christos Hadjichristodoulou supervised the surveillance activities.

Evaggelia Papanikolaou, Irene Terzaki, Lambrini Veneti, Anna Vakali and Georgios Dougas provided the surveillance data from the case investigations.

Anna Papa and Athanasios Tsakris provided the laboratory data of the human cases.

Constantina Politis and Kostas Stamoulis provided the haemovigilance findings and data on surveillance in the blood donor population.

All authors were members of the WNV outbreak response team. All authors read and critically revised the first as well as the subsequent drafts of this manuscript and approved the final version.

References $^{*}$

1. World Health Organization (WHO). West Nile virus. Fact sheet $\mathrm{N}^{\circ} 354$, July 2011. Geneva: WHO; 2011. Available from: http:// www.who.int/mediacentre/factsheets/fs354/en/

2. Calistri P, Giovannini A, Hubalek Z, Ionescu A, Monaco F, Savini G, et al. Epidemiology of West Nile in Europe and in the Mediterranean basin. Open Virol J. 2010;4:29-37.

3. European Centre for Disease Prevention and Control (ECDC). Review of the epidemiological situation of West Nile Virus infection in the European Union. Update 19 September 2011. Rapid Risk Assessment: Stockholm: EDC; 2011. Available from: http://www.ecdc.europa.eu/en/publications/ Publications/110920_TER_Rapid\%20risk\%20assessment_WNF. pdf

4. Marka A, Diamantidis A, Papa A, Valiakos G, Chaintoutis SC, Doukas D, et al. West Nile virus state of the art report of MALWEST Project. Int J Environ Res Public Health. 2013;10(12):6534-6610. http://dx.doi.org/10.339o/ijerph10126534

5. Centers for Disease Control and Prevention (CDC). Clinical evaluation \& disease. West Nile virus. Atlanta, GA: CDC. [Accessed 6 Jan 2014]. Available from: http://www.cdc. gov/westnile/healthCareProviders/healthCareProviders ClinLabEval.html

6. Danis K, Papa A, Papanikolaou E, Dougas G, Terzaki I, Baka A, et al. Ongoing outbreak of West Nile virus infection in humans, Greece, July to August 2011. Euro Surveill. 2011;16(34): pii=19951. 
7. Bakonyi T, Ivanics E, Erdélyi K, Ursu K, Ferenczi E, Weissenböck $\mathrm{H}$, et al. Lineage 1 and 2 strains of encephalitic West Nile virus, central Europe. Emerg Infect Dis. 2006;12(4):618-23. http://dx.doi.org/10.3201/eid1204.051379

8. Bakonyi T, Ferenczi E, Erdélyi K, Kutasi O, Csörgö T, Seidel $B$, et al. Explosive spread of a neuroinvasive lineage 2 West Nile virus in Central Europe, 2008/2009. Vet Microbiol. 2013 26;165(1-2):61-70.

9. Platonov AE, Fedorova MV, Karan LS, Shopenskaya TA, Platonova OV, Zhuravlev VI. Epidemiology of West Nile infection in Volgograd, Russia, in relation to climate change and mosquito (Diptera: Culicidae) bionomics. Parasitol Res. 2008;103 Suppl 1:S45-53. http://dx.doi.org/10.1007/s00436-008-1050-0

10. Wodak E, Richter S, Bagó Z, Revilla-Fernández S, Weissenböck $\mathrm{H}$, Nowotny $\mathrm{N}$, et al. Detection and molecular analysis of West Nile virus infections in birds of prey in the eastern part of Austria in 2008 and 2009. Vet Microbiol. 2011;149(3-4):358-66. http://dx.doi.org/10.1016/j.vetmic.2010.12.012

11. Pavlatos M, Smith CE. Antibodies to arthropod-borne viruses in Greece. Trans R Soc Trop Med Hyg. 1964;58:422-4. http://dx.doi.org/10.1016/0035-9203(64)90089-6

12. Antoniadis A, Alexiou-Daniel S, Malissiovas N, Doutsos J, Polyzoni T, Leduc JW, et al. Seroepidemiological survey for antibodies to arboviruses in Greece. Arch Virol. 1990;Suppl 1:277-85.

13. Papa A, Perperidou P, Tzouli A, Castiletti C. West Nile virus-neutralizing antibodies in humans in Greece. Vector Borne Zoonotic Dis. 2010;10(7):655-8. http://dx.doi.org/10.1089/vbz.2010.0042

14. Tsai TF, Popovici F, Cernescu C, Campbell GL, Nedelcu NI. West Nile encephalitis epidemic in southeastern Romania. Lancet.1998;352(9130):767-71. http://dx.doi.org/10.1016/S0140-6736(98)03538-7

15. Danis K, Papa A, Theocharopoulos G, Dougas G, Athanasiou M, Detsis $M$, et al. Outbreak of West Nile virus infection in Greece, 2010. Emerg Infect Dis. 2011;17(10):1868-72. http://dx.doi.org/10.3201/eid1710.110525

16. Ladbury GA, Gavana M, Danis K, Papa A, Papamichail D, Mourelatos S, et al. Population seroprevalence study after a West Nile virus lineage 2 epidemic, Greece, 2010. PLoS One. 2013;8(11):e80432. http://dx.doi.org/10.1371/journal.pone.0080432

17. Papa A, Danis K, Baka A, Bakas A, Dougas G, Lytras T, et al. Ongoing outbreak of West Nile virus infections in humans in Greece, July-August 2010. Euro Surveill. 2010;15(34): $\mathrm{pii}=19644$.

18. Biggerstaff BJ, Petersen LR. Estimated risk of transmission of the West Nile virus through blood transfusion in the US, 2002. Transfusion. 2003;43(8):1007-17. http://dx.doi.org/10.1046/j.1537-2995.2003.00480.x

19. European Commission (EC). West Nile virus and blood safety. Introduction to a preparedness plan in Europe. Based on the EU Satellite Meeting of the Working Group on Blood Safety and WNV, Thessaloniki, 25-26 January 2011 And on the teleconference, 18 January 2012 . Final working document 2012 v.2.1. Prepared by: Greece, Italy, Romania and France. Brussels: EC: 2012. Available from: http://ec.europa.eu/ health/blood_tissues_organs/docs/wnv_preparedness plan 2012.pdf

20. Politis C, Tsoukala A, Hatzitaki M, Pappa A, Englezou A, Zafeiriou C, et al. West Nile Virus (WNV) outbreak in Greece and blood safety measures. Vox. Sang. 2011;101(Suppl.1):42 (3D-S12-03).

21. Politis C, Pappa A, Hassapopoulou H, Pantelidou D, Perifanis V, Teli A, et al Transfusion transmitted West Nile Virus (WNV) infection in thalassaemic patients in Greece.Vox Sang. 2011;101 (Suppl.1):236 (P-390).

22. Papa A, Xanthopoulou K, Gewehr S, Mourelatos S. Detection of West Nile virus lineage 2 in mosquitoes during a human outbreak in Greece. Clin Microbiol Infect. 2011;17(8):1176-80. http://dx.doi.org/10.1111/j.1469-0691.2010.03438.x

23. Papa A, Bakonyi T, Xanthopoulou K, Vásquez A, Tenorio A, Nowotny N. Genetic characterization of a neuroinvasive lineage 2 West Nile virus, Greece, 2010. Emerg Infect Dis. 2011;17(5):920-2. http://dx.doi.org/10.3201/eid1705.101759

24. Valiakos G, Touloudi A, lacovakis C, Athanasiou L, Birtsas P, Spyrou V, et al. Molecular detection and phylogenetic analysis of West Nile virus lineage 2 in sedentary wild birds (Eurasian magpie), Greece, 2010. Euro Surveill. 2011;16(18):pii=19862.

25. Papa A, Politis C, Tsoukala A, Eglezou A, Bakaloudi V, Hatzitaki $M$, et al. West Nile virus lineage 2 from blood donor, Greece. Emerg Infect Dis. 2012;18(4):688-9. Availablefrom: http:// dx.doi.org/10.3201/eid1804.110771 http://dx.doi.org/10.3201/eid1804.110771
26. Papa A, Xanthopoulou K, Tsioka A, Kalaitzopoulou S, Mourelatos S. West Nile virus in mosquitoes in Greece. Parasitol Res. 2013;112(4):1551-5. http://dx.doi.org/10.1007/s00436-013-3302-x

27. Chaskopoulou A, Dovas CI, Chaintoutis SC, Bouzalas I, Ara G, Papanastassopoulou M. Evidence of enzootic circulation of West Nile virus (Nea Santa-Greece-2010, lineage 2), Greece, May to July 2011. Euro Surveill. 2011;16(31):pii=19933.

28. European Commission. Commission Decision of $28 /$ IV/2008 amending Decision 2002/253/EC laying down case definitions for reporting communicable diseases to the Community network under Decision No 2119/98/EC of the European Parliament and of the Council. Official Journal of the European Union. Luxembourg: Publications Office of the European Union. 18.06.2008:L 159. Available from: http://eur-lex.europa.eu/ legal-content/EN/TXT/PDF/?uri=CELEX:32008D 0426\&from=EN

29. International Organization for Standardization (ISO). Date and time format - ISO 8601. Geneva: ISO. [Accessed 15 Jan 2013]. Available from: http://www.iso.org/iso/home/standards/ is $08601 . h t m$

30. Commission Directive 2004/33/EC of 22 March 2004 implementing Directive 2002/98/EC of the European Parliament and of the Council as regards certain technical requirements for blood and blood components. Official Journal of the European Union Luxembourg: Publications Office of the European Union. 30.3.2004:L91. Available from: http://eur-lex. europa.eu/legal-content/EN/TXT/PDF/?uri=CELEX:32004Lo03 $3 \&$ from $=\mathrm{EN}$

31. Linke S, Ellerbrok H, Niedrig $M$, Nitsche A, Pauli G. Detection of West Nile virus lineages 1 and 2 by real-time PCR. J Virol Methods. 2007;146(1-2):355-8. http://dx.doi.org/10.1016/j.jviromet.2007.05.021

32. Sánchez-Seco MP, Rosario D, Domingo C, Hernández L, Valdés K, Guzmán MG, et al. Generic RT-nested-PCR for detection of flaviviruses using degenerated primers and internal control followed by sequencing for specific identification. J Virol Methods. 2005;126(1-2):101-9. http://dx.doi.org/10.1016/j.jviromet.2005.01.025

33. Kacian DL, Fultz TJ. Nucleic acid sequence amplification methods. United States patent US 5,399,491. 1995.

34. Saldanha J, Shead S, Heath A, Drebot M; West Nile Virus Collaborative Study Group. Collaborative study to evaluate a working reagent for West Nile virus RNA detection by nucleic acid testing. Transfusion. 2005;45:97-102. http://dx.doi.org/10.1111/j.1537-2995.2005.04151.x

35. Hellenic Statistical Authority (EL.STAT.). Resident population, surface area and population density, by urban and rural areas, and by level, semi-mountainous and mountainous areas. Altitude mean weighted coefficient. a) Greece Total and Geographic Departments. 2001 Population Census. Piraeus: EL.STAT. [Accessed 13 January 2013]. Greek. Available from: http://www.statistics.gr/portal/page/portal/ESYE/BUCKET/ A1602/Other/

36. Gabriel M, Emmerich P, Frank C, Fiedler M, Rashidi-Alavijeh J, Jochum C, et al. Increase in West Nile virus infections imported to Germany in 2012. J Clin Virol. 2013;58(3):587-9. http://dx.doi.org/10.1016/j.jcv.2013.08.027

37. Barzon L, Papa A, Pacenti M, Franchin E, Lavezzo E, Squarzon $L$, et al. Genome sequencing of West Nile Virus from human cases in Greece, 2012. Viruses. 2013;5(9):2311-9. http://dx.doi.org/10.3390/v5092311

38. Papa A, Karabaxoglou D, Kansouzidou A. Acute West Nile virus neuroinvasive infections: cross-reactivity with dengue virus and tick-borne encephalitis virus. J Med Virol. 2011;83(10):1861-5. http://dx.doi.org/10.1002/jmv.22180

39. Hellenic Center for Disease Control \& Prevention. Weekly epidemiological report for the West Nile virus disease, Greece, 2013 - 06 November 2013. Athens: HCDCP; 2013. Available from: http://www.keelpno.gr/Portals/o/Files/English\%20 files/WNV\%20reports\%202012/Weekly_Reports_2013/WNV_ weekly\%20report_2013_11_06.pdf

40. European Centre for Disease Prevention and Control (ECDC). Table on cases - 2012. West Nile fever maps. Stockholm: ECDC. [Accessed 18 Jul 2013]. Available from: http://www.ecdc. europa.eu/en/healthtopics/west_nile_fever/West-Nile-fevermaps/Pages/2012-table.aspx

41. Hellenic National Meteorological Service. Climatic bulletins of June 2010, June 2011, June 2012. Hellinikon: Hellenic National Meteorological Service. [Accessed 22 Jun 2013]. Available from: http://www.hnms.gr/hnms/english/climatology/ climatology month html?dr month $=06$

42. Papa A, Papadopoulou E, Gavana E, Kalaitzopoulou S, Mourelatos S. Detection of West Nile virus lineage 2 in Culex mosquitoes, Greece, 2012. Vector Borne Zoonotic Dis. 2013;13(9):682-4

http://dx.doi.org/10.1089/vbz.2012.1212 
43. O'Leary DR, Marfin AA, Montgomery SP, Kipp AM, Lehman JA, Biggerstaff BJ, et al. The epidemic of West Nile virus in the United States, 2002. Vector Borne Zoonotic Dis. 2004;4(1):6170.

http://dx.doi.org/10.1089/153036604773083004

44. Han LL, Popovici F, Alexander JP Jr, Laurentia V, Tengelsen LA, Cernescu C, et al. Risk factors for West Nile virus infection and meningoencephalitis, Romania, 1996. J Infect Dis. 1999;179(1):230-3.

http://dx.doi.org/10.1086/314566

45. Lindsey NP, Staples JE, Lehman JA, Fischer M; Centers for Disease Control and Prevention (CDC). Surveillance for human West Nile virus disease-United States, 1999-2008. MMWR Surveill Summ. 2010;59(2):1-17.

46. Weinberger M, Pitlik SD, Gandacu D, Lang R, Nassar F, Ben David D, et al. West Nile fever outbreak, Israel, 2000: epidemiologic aspects. Emerg Infect Dis. 2001;7(4):686-91. http://dx.doi.org/10.3201/eid0704.017416

47. Weiss D, Carr D, Kellachan J, Tan C, Phillips M, Bresnitz E, et al. Clinical findings of West Nile virus infection in hospitalized patients, New York and New Jersey, 2000. Emerg Infect Dis. 2001;7(4):654-8. http://dx.doi.org/10.3201/eido704.017409

48. Nash D, Mostashari F, Fine A, Miller J, O'Leary D, Murray K, et al. The outbreak of West Nile virus infection in the New York City area in 1999. N Engl J Med. 2001;344(24):1807-14 http://dx.doi.org/10.1056/NEJM200106143442401

49. Chowers MY, Lang R, Nassar F, Ben-David D, Giladi M, Rubinshtein E, et al. Clinical characteristics of the West Nile fever outbreak, Israel, 2000. Emerg Infect Dis. 2001;7(4):675-8 http://dx.doi.org/10.3201/eido704.017414

50. Bode AV, Sejvar JJ, Pape WJ, Campbell GL, Marfin AA. West Nile virus disease: a descriptive study of 228 patients hospitalised in a 4-county region of Colorado in 2003.Clin Infect Dis. 2006;42(9):1234-40. http://dx.doi.org/10.1086/503038

51. Murray K, Baraniuk S, Resnick M, Arafat R, Kilborn C, Cain K, et al. Risk factors for encephalitis and death from West Nile virus infection. Epidemiol Infect. 2006;134(6):1325-32. http://dx.doi.org/10.1017/So950268806006339

52. Patnaik JL, Harmon H, Vogt RL. Follow-up of 2003 human West Nile virus infections, Denver, Colorado. Emerg Infect Dis. 2006;12(7):1129-31. http://dx.doi.org/10.3201/eid1207.051399

53. Sirbu A, Ceianu CS, Panculescu-Gatej RI, Vazquez A, Tenorio $A$, Rebreanu R, et al. Outbreak of West Nile virus infection in humans, Romania, July to October 2010. Euro Surveill. 2011;16(2):pii=19762.

54. Rizzo C, Salcuni P, Nicoletti L, Ciufolini MG, Russo F, Masala R, et al. Epidemiological surveillance of West Nile neuroinvasive diseases in Italy, 2008 to 2011. Euro Surveill. 2012;17(20): $\mathrm{pii}=20172$.

55. Lindsey NP, Staples JE, Lehman JA, Fischer M. Medical risk factors for severe West Nile Virus disease, United States, 2008-2010. Am J Trop Med Hyg. 2012;87(1):179-84. http://dx.doi.org/10.4269/ajtmh.2012.12-0113

56. Hellenic Statistical Authority (EL. STAT.). Estimated population by sex and 5year age groups on 1st January (Years 1991. 2012). Piraeus: EL. STAT. [Accessed 15 Jan 2013]. Available from: http://www.statistics.gr/portal/page/portal/ESYE/ PAGE-themes?p_param $=A 1605 \&$ r_param $=S P 018 \& y_{-}$ param $=2012 \_00 \&$ mytabs $=0$ 